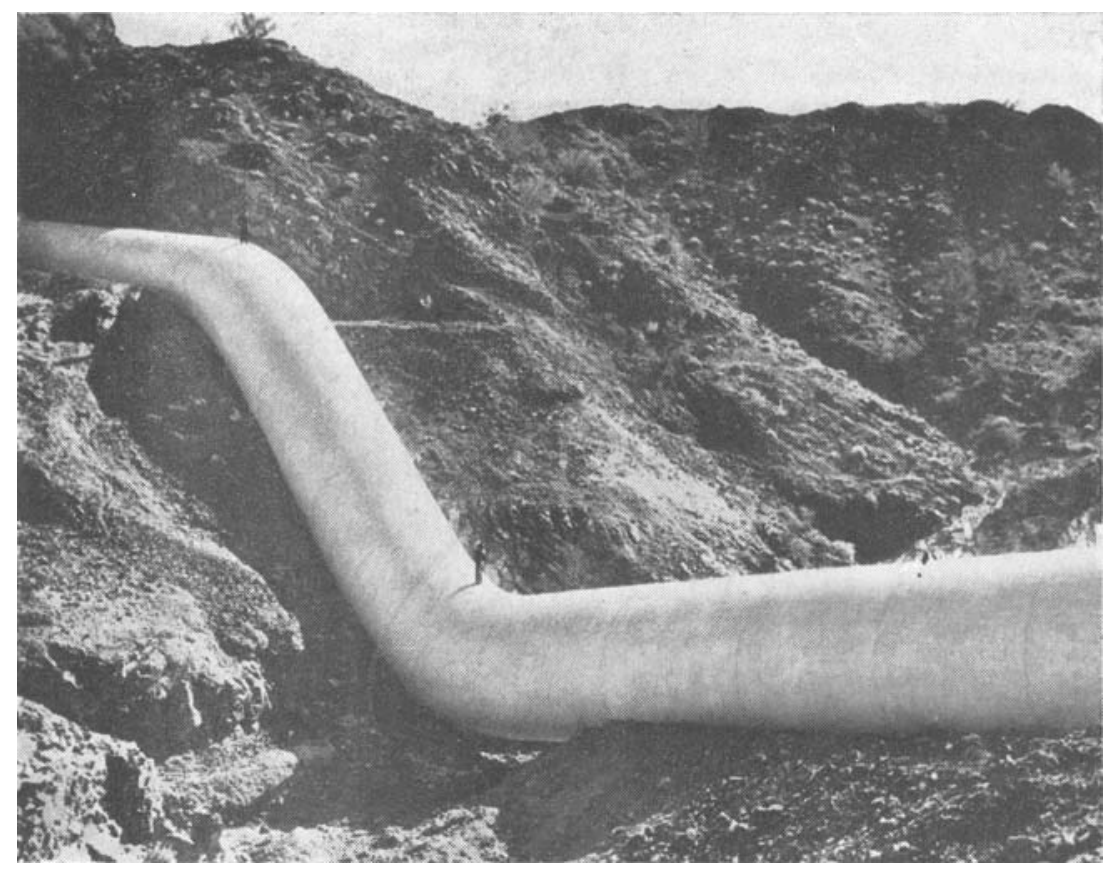

\title{
Water -
}

Water, an industrial mineral, doesn't go to market in freight cars but moves in giant conduits. Here is a steel-reinforced concrete inverted siphon, $16 \mathrm{ft}$ in diameter.

Industrialization is raising the standard of living of people everywhere. The common man is demanding and getting more of everything. Perhaps more markedly than most other things, he is consuming more water. A hundred years ago water for domestic use, in all but a few large centers, was lugged from wells in buckets. This still is true in many rural areas, even in the enlightened United States of America, but pumps and pressure systems are rapidly replacing the "old oaken bucket," even on farms and in isolated country homes. Nevertheless,

A paper presented before the Industrial Minerals Division, AIME, at the Oct. 24 meeting in Los Angeles. many still fail to see water as a "commodity," in the same sense that coal, lumber, fertilizer, and bread are considered as commodities. Water is too frequently taken for granted.

If a mining man needs more air for a shaft or adit, he simply installs another blower and takes it from the conveniently adjacent atmosphere. The industrialist, needing more air for a factory or building, does the same thing. The availability of an inexhaustible supply of air for such uses is fortunate. It also would be fortunate if other elements essential to human activities were equally available, but, of course, they are not. Food, clothing,

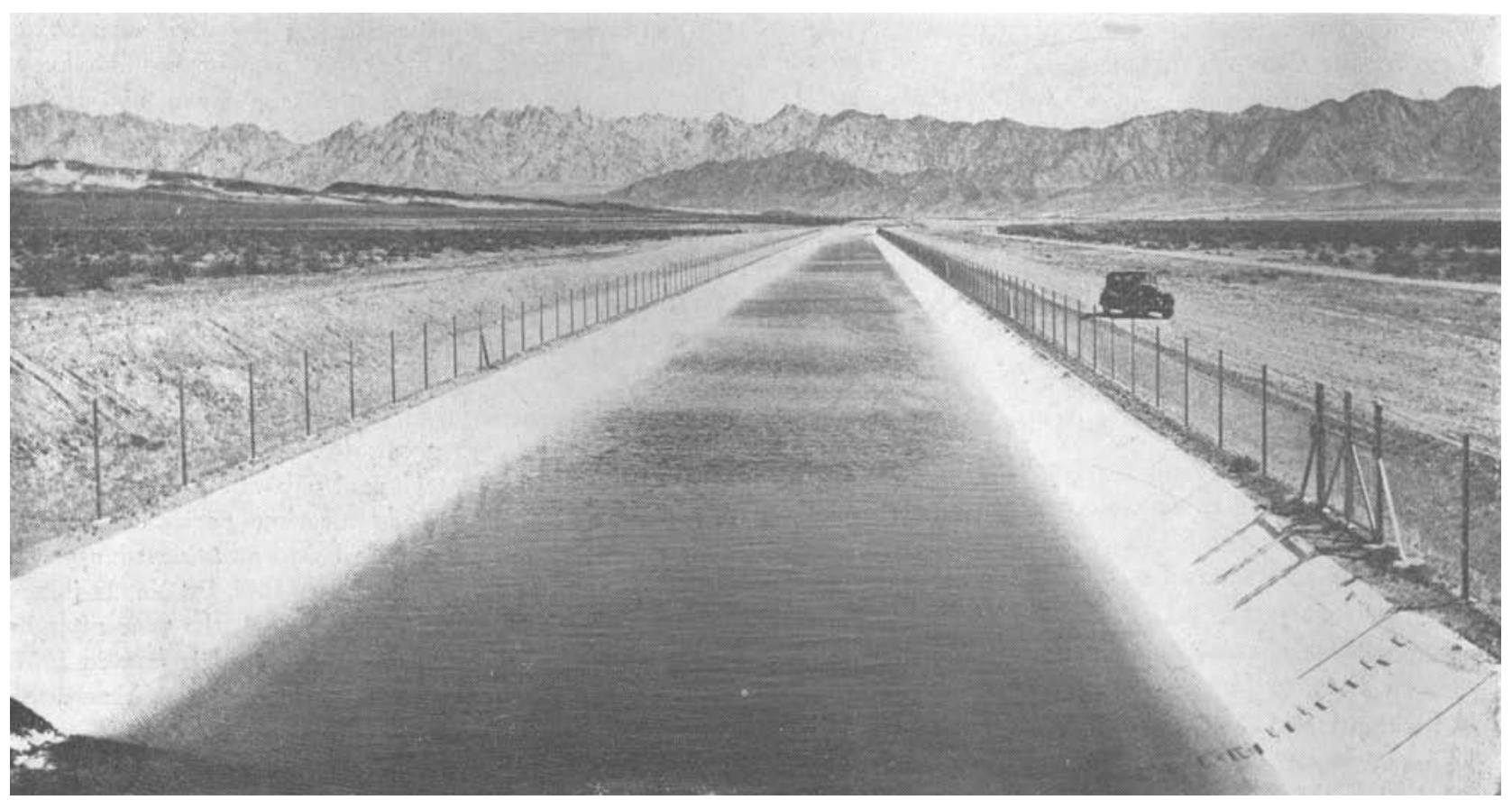

Transporting water by canal is one way to get it there. There are 63 miles of concrete-lined open canals in the 242 -mile main aqueduct system which carries water from Lake Havasu to three million inhabitants of Southern California. 


\section{Lowest Cost Industrial Mineral}

By JULIAN HINDS - CENERAL MANACER, METROPOLITAN WATER DISTRICT, LOS ANGELES

shelter, and the thousand and one things required to meet modern needs are obtainable only at the expense of exertion.

There was a time when water for most people and for most purposes was almost as abundant as air. Our not too distant ancestors, thinly scattered over humid areas or grouped in small numbers about oases, gave little thought to water as a problem-except in times of unusual drought. If more water was needed, another bucket was sent to the spring or stream, or another shallow well was dug. Increasing numbers and the spreading of populations into arid regions have changed this. Water has become one of the elements that must be striven for.

This change has come about so gradually that the average man on the street is not too painfully aware of it. The city dweller thinks of water as something that comes out of faucets. If he wants more water, he buys another faucet, little aware of the effort often required to find the water, refine it, and pipe it to his outlet. Ordinarily, this is as it should be. Production is left to experts, just as the production of coal or copper is left to the expert miner and metallurgist.

At times, however, the consumer needs to give serious thought to the nature and adequacy of the source of his

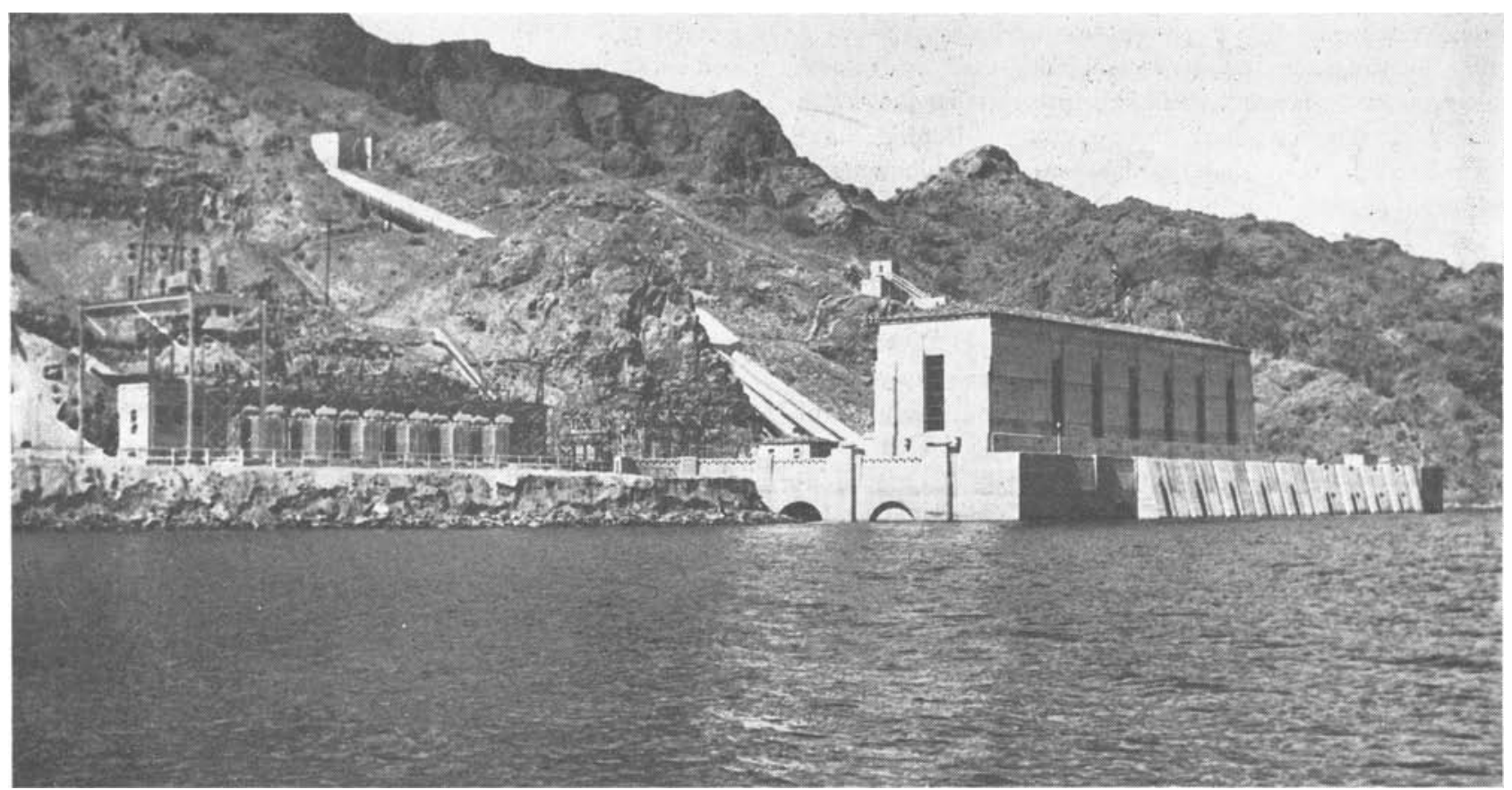

Lake Havasu reservoir is a stock pile of water for the South arn California area market. The building in the picture is the intake pumping station which starts the water on its way over the longest man-made aqueduct system in the world. 


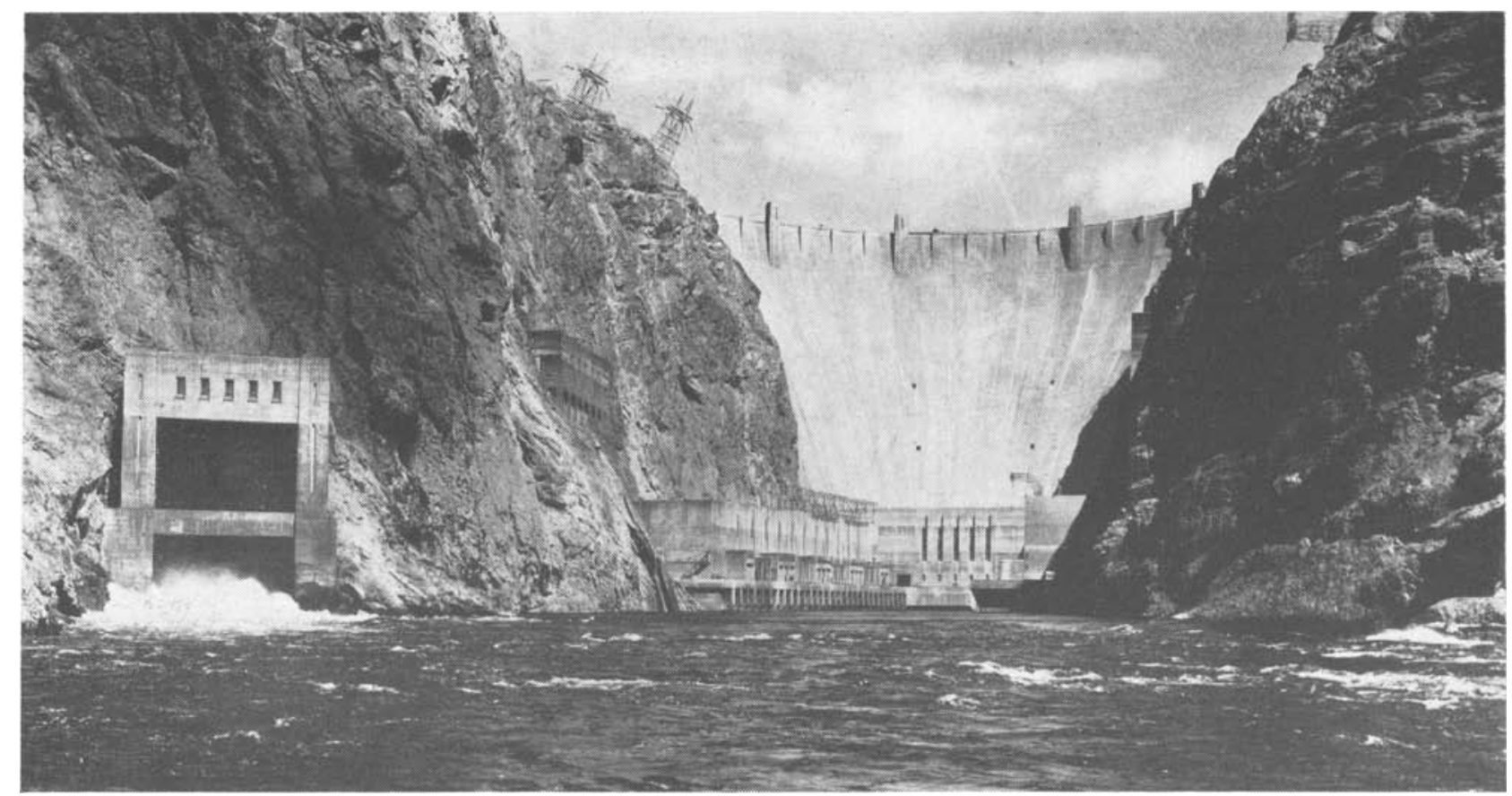

Hoover Dam, keystone of the Colorado River aqueduct development program, measures $727 \mathrm{ft}$ from foundation to crest.

water. This applies to the home owner as well as the miner about to open a milling plant in an arid region. It applies particularly to those proposing to initiate waterconsuming industrial enterprises.

Unfortunately, water is all too frequently the last thing a promoter thinks of. This was particularly true during the war. Factories and housing projects were built with great abandon on flat spots that could be bought cheaply, only to discover too late that the site was cheap because it had no water.

The same thing can happen in peacetime. As a recent example, the promoter of a postwar cement project in southern California acquired suitable deposits in the desert, arranged for a power supply, expended great effort locating the required machinery, and was about ready to start construction before investigating the water supply. There was none. Mining ventures likewise have been developed and abandoned because of inadequacy of water supply - a condition which should have been foreseen. The same careful advance consideration should be given to water as is given to power, raw materials, and other essentials.

The water system built along the Colorado River aqueduct of the Metropolitan Water District, to supply water for construction purposes, affords a good example of water planning for a specific enterprise. This great waterway was to be built 250 miles across a desert, devoid for much of this distance of any visible water for the maintenance of life or for construction purposes. Careful reconnaissance indicated the possible presence of underground bodies of water in rather widely separated desert basins; many were salty, but usable supplies were found at forty- to fifty-mile intervals. Obviously, it would have been uneconomical to require each individual contractor to transport water over such distances. Consequently, as a preconstruction enterprise, the District developed all of these sources, provided pumps and storage reservoirs, and laid a construction water line for the full length of the project. Fifteen usable wells, varying from 16 to $785 \mathrm{ft}$ in depth, were drilled in half a dozen locations. There were also a number of salt wells and "dusters." The supply line consisted of 180 miles of 5-, 6-, and 8-in. diameter lightweight, continuously-welded steel pipe, laid in shallow trenches. The total cost of the system was $\$ 847,000$ and it was much more than worth it. The supply was adequate.

Such elaborate planning of a water supply for an individual project is, of course, unusual. Most large enterprises can tap some community water system. Before risking any great investment, however, both source of supply and adequacy of delivery system should be investigated.

Most water-supply systems have grown more or less piecemeal, starting with a few families and expanding by various expedients with the growing population, systematic planning being introduced at some later date to avoid an impending disaster. In this way, the great modern water developments of the world have grown.

A most interesting example is found in the development of water in southern California. The white man found this an arid region, an excellent place for a few people to live, but subject to severe and prolonged droughts. During wet periods there were lush pastures, springs, and flowing streams, encouraging increased development, expansion of herds, and the introduction of irrigation. Then came drought. Irrigation ditches ran dry, cattle died, and people moved away. But in spite of these periods of discouragement, there was some permanent development. The climate was good, soil fertile, and all kinds of fruits and crops flourished wherever and whenever there was water.

Ground water as a source of irrigation supply was not at first taken seriously, but wells were, of course, resorted to for domestic supplies, and at times of drought for 
watering livestock and perhaps for home gardens. The early dug wells merely tapped shallow surface sources, but finally, with the introduction of the drilled well, someone pierced the clay cap and struck a gusher-a bountiful artesian flow. The boom was on! Here were vast expanses of wonderfully fertile lands, with a bountiful water supply just a few hundred dollars beneath the surface. Development went forward at a stupendous rate. Nobody asked where the water came from, how much there was, or how long it would last. There was no organization to ask such questions and the individual farmer was too busy to ask anything. The supply was looked upon as inexhaustible, and wells multiplied.

Soon outflow began to exceed replenishment. Pressures dropped and wells ceased to flow. But the farmers. now grown wealthy, were loath to walk off and leave their homesteads. Furthermore, they could now afford to pay for water-they could afford to pump it. And so pumps went down as fast as artesian flows stopped. And more pumping wells were drilled, still with the feeling that there were great underground oceans of fresh water, to all intents and purposes inexhaustible. And thus began one of the most stupendous mining operations of all time.

As geologists later explained, there actually was a vast, though not inexhaustible, underground storehouse of water. Practically the entire coastal basin is deeply underlain with porous detrital fills, covered with a blanket of topsoil and clay of varying thickness. Each year a small portion of the sparse rainfall and meager mountain runoff around the upper perimeter of the basin sinks into the ground. During prehistoric ages these small percolations completely filled the underlying strata and welled up against the clay cap covering the lower portions, creating an artesian pressure. It was thus revealed that the early settler's herds had died of thirst on the roof of an enormous lake of good water.

But it was only a lake and not an inexhaustible sea of fresh water, as many wishfully believed. With increased pumping, water levels sank and many wells went dry, or lowered levels permitted sea water to flow landward, contaminating the source of supply. Ultimate exhaustion became obvious, but abandonment was by now out of the question. Experts were employed and the problem was studied from all its angles. Steps were taken looking toward complete conservation of all flood waters formerly wasting into the ocean. Spreading works were constructed to encourage percolation into the underground basin, and surface storage was created where possible.

But these measures were inadequate. An annual rainfall of 15 in., no matter how thoroughly it is conserved, cannot support a semitropical civilization. Importation of water was obviously essential. There is no long river bringing water in naturally from distant sources, and near-by surrounding territory is true desert, producing no worth-while runoff. So, early in the present century it became evident that an artificial waterway to some distant point must be constructed. As a result, the then small City of Los Angeles voted the stupendous sum of $\$ 23,000,000$ to build an aqueduct to tap the Owens River, 250 miles to the north. This river collects the drainage from the precipitous eastern slopes of Mt. Whitney and

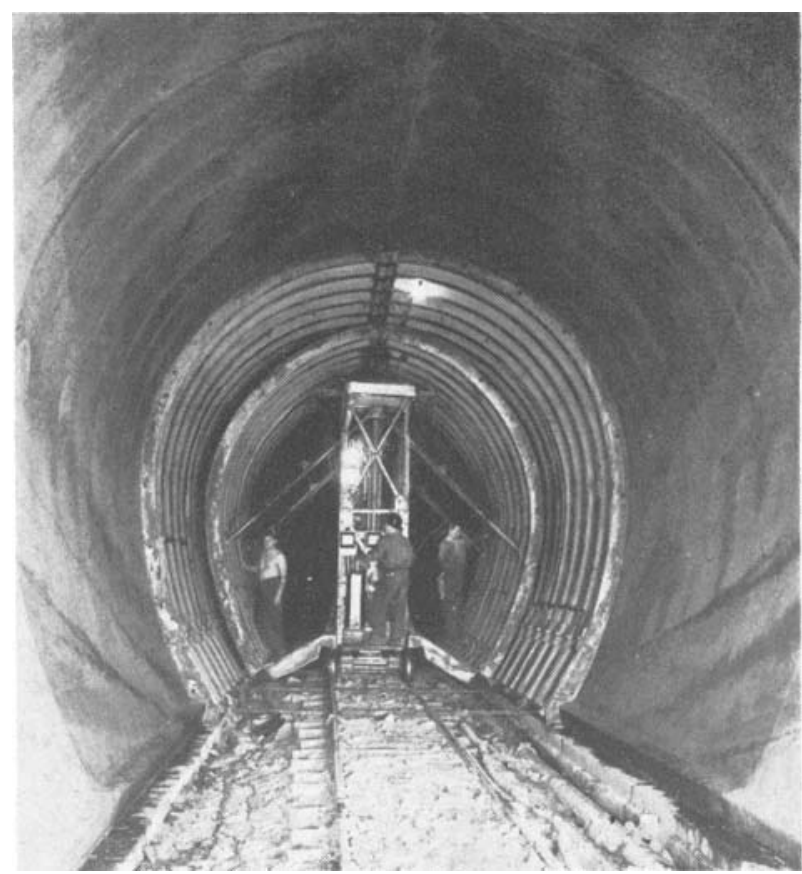

Setting steel to reinforce concrete in a $16-\mathrm{ft}$ high conduit.

other snow-capped mountain peaks of the High Sierras.

The aqueduct was completed in 1913 with a capacity of $450 \mathrm{cfs}$. It was expected to end the water needs of Los Angeles for all time. But just as the discovery of artesian flow engendered overdevelopment, so did the introduction of Owens River water. The inexhaustible idea was again rampant, and the city began doubling in population every ten years. Leaders soon saw that the battle for water had just begun and eyes were turned to the only other adequate source-the Colorado Riverfrequently referred to as "the last water hole of the Southwest."

Water from the Colorado River for the coastal areas of southern California could be obtained only from the flood flows. Normal low flows were already completely appropriated. The creation of storage on the main river was not a job for a single community. The stream is interstate (in fact, international), floods are great, and silt is a problem. The political situation was complex. But the problem was courageously attacked and solved.

The amount of work involved has been prodigious. Interstate compacts, enabling acts in Sacramento and Washington, and contracts and agreements on a national scale consumed unimaginable time and effort. Finally. construction of Hoover Dam by the U. S. Bureau of Reclamation was authorized. The Metropolitan Water District, comprising the principal cities of the South Coastal Plain, was organized, and $\$ 220,000,000$ worth of bonds was voted to build an aqueduct to bring more than one million acre feet per year of the conserved water to the needy coastal communities. The job was started in the bottom of the depression and finished just before the beginning of the war, substantially under the original estimate of cost.

This aqueduct again was expected permanently to end the water worries of southern California. It is now evident that this is not the case. The necessity for some 


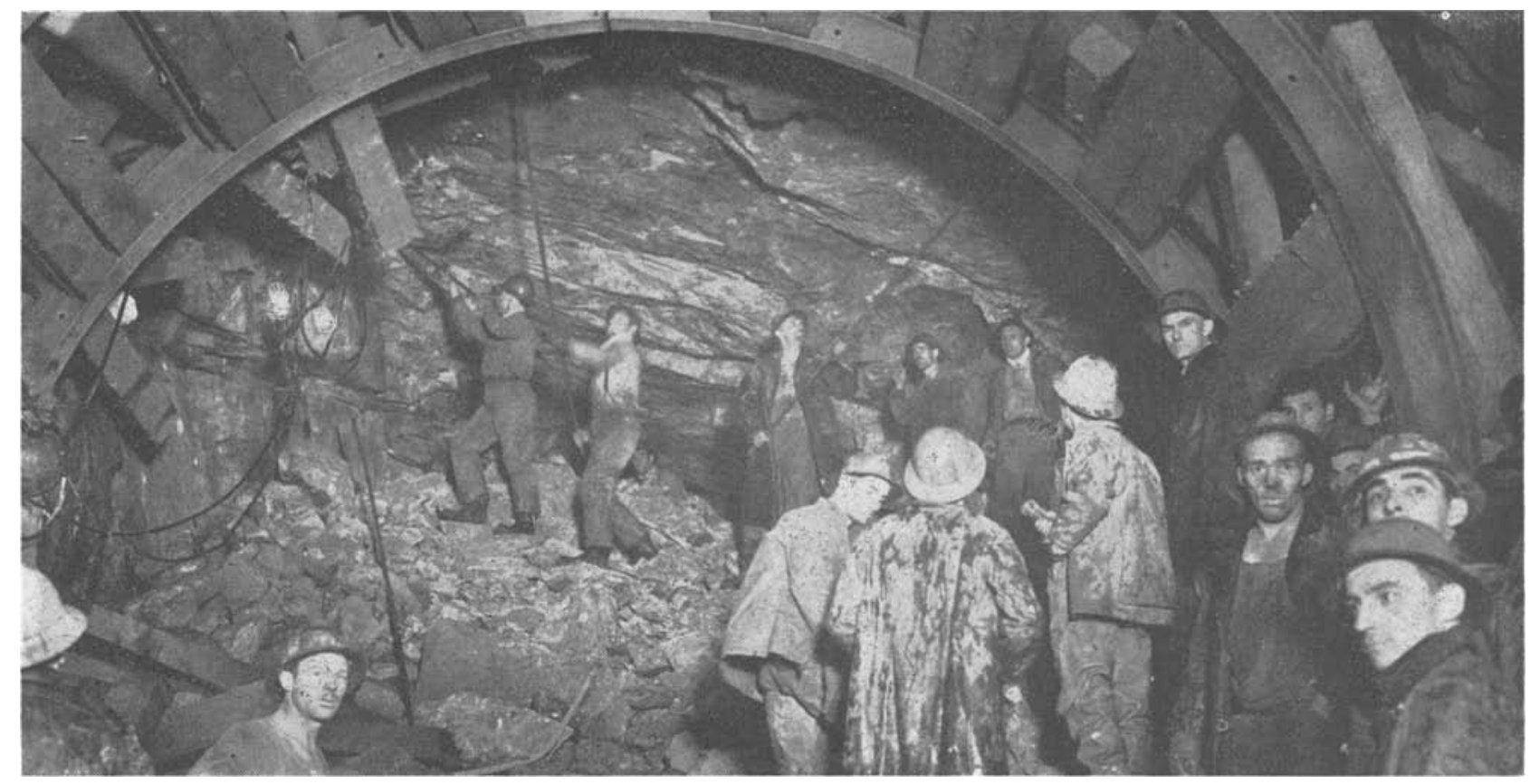

Barring dawn after the blast which holed through the San Jacinto tunnel. This tunnel pierced 13.04 miles of solid rock in the San Jacinto mountain range and was the most difficult unit of the entire metropolitan aqueduct construction.

limitation of ultimate development is likely unless an additional source beyond "the last water hole" is found and tapped.

This story illustrates the effort involved in planning for a water supply. Most systems are, of course, smaller and simpler. Many of them have been planned with relatively as much care as that described, but usually with less elaborateness. Many small municipal and private systems are still going largely on faith and although usually adequate for ordinäry needs, cannot stand a sudden expansion of demand. A prospective investor should carefully check the adequacy of such supplies.

Reference has been made to the extraction of ground waters in the southern California coastal area as a mining operation. Water being a mineral, this reference is perhaps justified by the dictionary definition of mining. The primary distinction between water mining and the mining of other minerals is that water is sometimes replenished by percolating rainfall, permitting the continued repetition of the mining operation. In the Los Angeles coastal area this was only partly true. In fact, the foundation of the present great civilization in this region was built on fossil waters, accumulated through countless prehistoric ages. These basins never again will be fully filled, and the "take" must now be limited to the annual crop. Nevertheless, the beneficial effect of the fossil waters was great. The artesian wells produced the wealth that could afford to pump; the pumped wells produced the wealth that could afford to build the Owens River aqueduct; and the supply from this source produced the wealth required to go to the Colorado River. If any of these links had been missing, the chain could not have been forged.

Production of water by mining operations is, of course, not limited to southern California. Well waters are used throughout the world for individual supplies, municipal supplies, and irrigation. Production is often deliberately undertaken on a pure mining basis, with no hope or expectation of replenishment. Desert lands underlain by nonreplenishing water bodies have been hurriedly put into cotton or other temporarily high-priced crops, with the hope of a quick return, and with the expectations of abandonment after a few years, but such operations are likely to be detrimental to adjacent lands depending on a perennial underground water crop.

Water, like other mineral products, must be transported to its points of use after it is "mined." Sometimes it also must be refined-that is, softened or otherwise purified. In contrast to most commodities, water is delivered right where it is wanted, as wanted. It is not necessary to go to the railway station, warehouse, or store, and haul it home; or to wheelbarrow it in from the front yard. Its delivery is complete and the price of delivery is ridiculously low.

When the Colorado River aqueduct shall have reached full development, it will be capable of transporting $12 / 3$ billion tons of water per year from 300 to 400 miles, lifting it through a height of over $1600 \mathrm{ft}$, and delivering it wholesale into the water systems of the coastal area at a cost slightly over one cent per ton, including interest on investment, depreciation, power for pumping, and all operation and maintenance costs. Refining (softening and filtration) will add another half cent per ton to the wholesale price. The retail price of water for household use in southern California will average about five cents a ton, delivered into the sink or bathtub, as and when needed. Irrigation and industrial water is much cheaper.

Thus the water producer sets a standard of economv which other producers and shippers will find it hard to approach-not because the water man's problems are easier, but because conditions favor low-cost production and because the volumes handled are so enormous. 